Jurnal Geocelebes Vol. 5 No. 1, April 2021, 55 - 62

\title{
GEOLOGI DAN MEKANISME STRUKTUR GEOLOGI DI DESA PERJIWA KECAMATAN TENGGARONG SEBERANG KABUPATEN KUTAI KARTANEGARA PROVINSI KALIMANTAN TIMUR
}

\author{
Resty Intan Putri, Diana Rahmawati*, Puspa Indah Rindawati, Adam Rahmad Firdaus, Ade \\ Santoso
}

Teknik Geologi, Universitas Mulawarman, Jl. Sambaliung No.9 Samarinda 75119, Indonesia

*Corresponding author. Email: diana.geologi.unmul@gmail.com

Manuscript received: 3 March 2021; Received in revised form: 27 April 2021; Accepted: 30 April 2021

\begin{abstract}
Abstrak
Daerah penelitian terletak di Desa Perjiwa, Kecamatan Tenggarong Seberang, Kabupaten Kutai Kartanengara. Penelitian ini bertujuan untuk mengetahui kondisi geologi meliputi kondisi geomorfologi, struktur geologi, stratigrafi dan mekanisme struktur geologi dari daerah penelitian. Metode pengambilan data difokuskan pada pengambilan data - data geologi permukaan, yang terdiri atas studi literatur, akuisisi data, analisa data. Geomorfologi daerah penelitian dibagi menjadi 2 (dua) bentuk asal yakni, bentuk asal struktural, dan bentuk asal fluvial. Bentuk asal struktural dengan bentuk lahan perbukitan tersayat, dan bentuk asal fluvial bentuk lahan dataran alluvial. Di daerah penelitian terdapat 3 satuan batuan yaitu satuan batuan batulempung Perjiwa, satuan batuan batupasir Bukit Raya dan endapan alluvial. Struktur geologi yang berkembang pada daerah penelitian adalah antiklin Perjiwa, sinklin Perjiwa, antiklin Separi, sinklin Bukit Raya, sesar naik Bukit Raya, sesar naik Tanjung Batu, sesar mendatar Tanjung, sesar naik KM 5. Mekanisme struktur geologi pertama adalah terbentuknya lipatan pada daerah penelitian. Semakin lama gaya yang bekerja semakin kuat sehingga batuan melewati batas elastisitasnya sehingga terbentuk sesar naik pada daerah penelitian, gaya semakin meningkat sehingga terbentuk sesar mendatar.
\end{abstract}

Kata Kunci: geologi; struktur geologi; mekanisme struktur geologi.

\begin{abstract}
The research area is located in the village of Perjiwa, Tenggarong Seberang District, Kutai Kartanengara Regency. This research aims to know the geological conditions such as geomorphology, structurul geology, stratigraphy, and geological structure mechanisms of the research area. The data acquisition method is focused on surface geological data, consisting of literature study, data acquisition, and data analysis. The geomorphology of the research area is divided into 2 landforms, structural and fluvial. The structural landform formed slashed hills, and fluvial landform created alluvial land. There are three lithological units in the research area, namely the claystone Perjiwa, the sandstone Bukit Raya and the alluvial deposits. The geological structure that constructed in the research area is the anticline Perjiwa, syncline Perjiwa, anticline Separi, syncline Bukit Raya, trust fault Bukit Raya, trust fault Tanjung Batu, strike-slip Tanjungbatu, and trust fault K.M 5. The first geological structural mechanism was formed folds in the research area. The longer the force that worked stronger so that the rocks pass through the elasticity boundary so that formed the trust fault in the research area, the force was increasing so that formed strike-slip fault.
\end{abstract}

Keywords: geology; geological structure, mechanism of geological structure. 


\section{Pendahuluan}

Geologi struktur merupakan salah satu cabang ilmu yang mempelajari proses dinamika bumi (Allen \& Chambers, 1998). Studi struktur geologi banyak digunakan dalam berbagai bidang contohnya seperti di bidang pertambangan, perminyakan, kebencanaan dan lain-lain. Munculnya unsur - unsur struktur seperti kekar, sesar, cermin sesar dan lain sebagainya sering menunjukkan pola yang kompleks dengan orientasi yang beragam (Nugraha, 2016). Merupakan suatu hal yang menarik untuk mengetahui penyebab terjadinya kompleksitas dan mempelajari proses yang bekerja pada produk geologi.

Di dalam Peta Geologi Regional Samarinda (Supriatna dkk., 1995), Kecamatan Tenggarong Seberang berada di daerah antiklin dan di dalam peta struktur geologi terdapat patahan/ sesar pada daerah tersebut (McClay dkk., 2000).

Berangkat dari latar belakang ini menyebabkan keingintahuan untuk membuktikan kebenaran di daerah tersebut terdapat struktur geologi yang begitu kompleks dengan melakukan penelitian pemetaan geologi di daerah Kecamatan Tenggarong Seberang, Kabupaten Kutai Kartanegara, Provinsi Kalimantan Timur untuk mengetahui tektonik dan proses pembentukan struktur pada lokasi tersebut.

\section{Metode Penelitian}

1. Studi literatur; kegiatan ini dimaksudkan untuk mencari literatur yang berhubungan dengan penelitian sehingga dapat membantu dalam pelaksanaan penelitian ini. Literatur dapat berupa buku, jurnal, skripsi yang berkaitan dengan penelitian ini serta menggunakan peta geologi regional untuk mengetahui lebih mendalam kondisi geologi di daerah penelitian.

2. Akuisisi data; pengambilan data primer dan data sekunder. Data primer merupakan data yang diambil di lapangan seperti pengamatan bentuk lahan, pengukuran kedudukan batuan, pengukuran bidang sesar dan kekar, pengukuran dan pengambilan contoh batuan. Data sekunder merupakan data citra satelit yang mendukung pengambilan data di lapangan.

3. Analisis data; tahap analisis geomorfologi terdiri atas pembagian satuan bentuk lahan, pembagian satuan bentuk lahan dibagi berdasarkan bentuk asal. Tahap analisis stratigrafi untuk mengetahui lingkungan pengendapan dari setiap satuan batuan. Tahap analisis struktur geologi menggunakan metode stereografis dan rekonstruksi lipatan. Tahap analisis mekanisme struktur geologi dengan cara merekonstruksi kejadian struktur geologi yang terjadi

\section{Hasil dan Pembahasan}

\section{Geomorfologi Daerah Penelitian}

Daerah penelitian dibagi menjadi 2 (dua) bentuk asal yakni bentuk asal struktural dan bentuk asal fluvial. Bentuk asal struktural memiliki satu bentuk lahan (Gambar 1) yaitu perbukitan tersayat disimbolkan dengan S1 dan bentuk asal fluvial memiliki bentuk lahan dataran alluvial dengan disimbolkan F1 yang dijelaskan sebagai berikut:

1. Bentuk asal struktural; bentuk asal struktral yang terbentuk akibat struktur geologi yang berkembang. Bentuk lahan ini merupakan bentuk lahan perbukitan tersayat. Bentuk lahan ini dicirikan adanya topografi yang bergelombang sedang hingga kuat dengan pola aliran yang berhubungan dengan kekar dan patahan. Hal ini tampak pada di lapangan yang banyak dijumpai patahan/ sesar dan kekar. Satuan bentuk lahan ini menempati $80 \%$ dari keseluruhan daerah penelitian. Morfologinya berupa perbukitan yang bergelombang dengan kelerengan sekitar 14-20\%. 


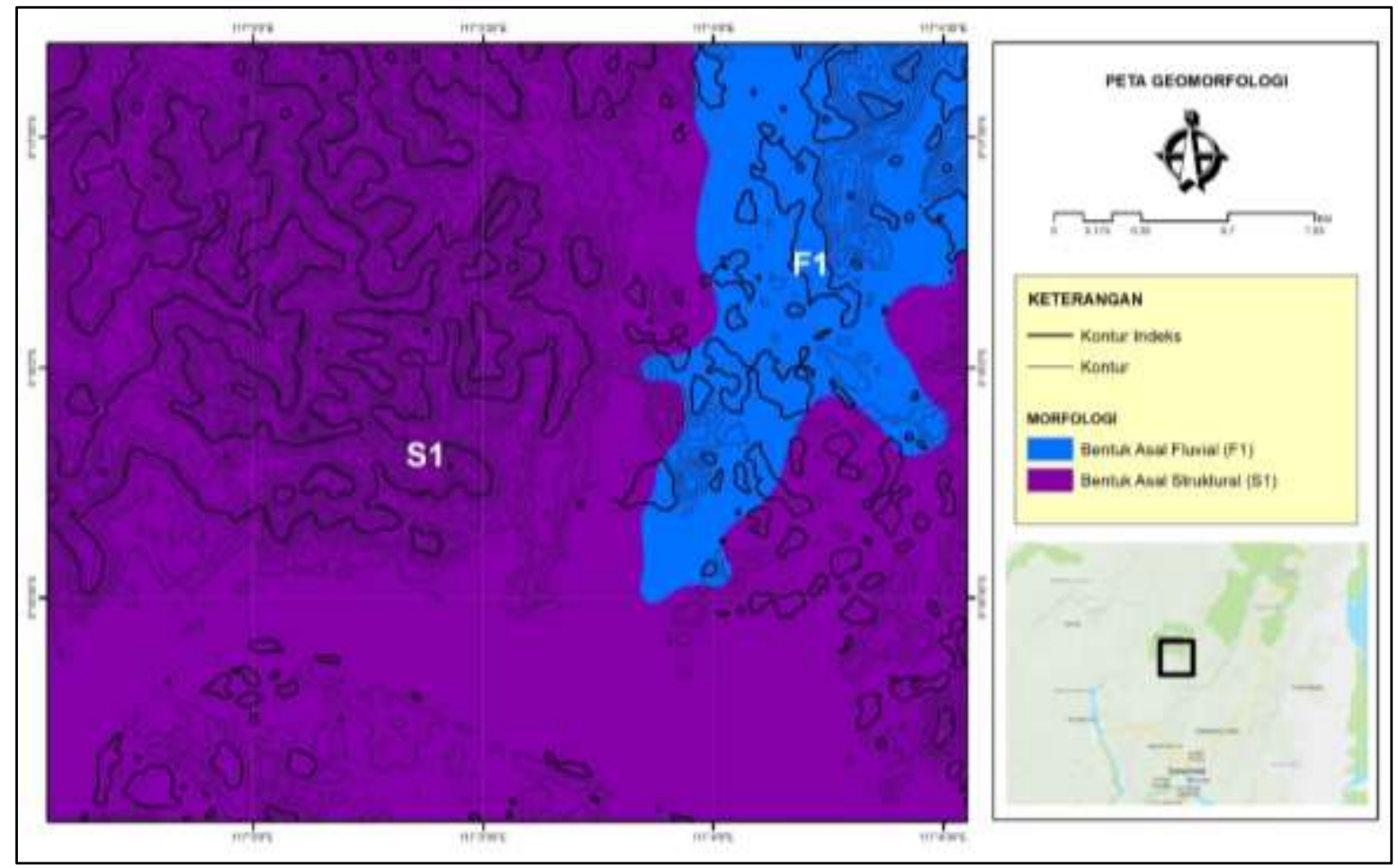

Gambar 1. Peta geomorfologi daerah penelitian.

2. Bentuk asal fluvial; bentuk asal fluvial yang terjadi akibat aktivitas sungai berupa pengikisan, pengangkutan dan pengendapan (sedimentasi) membentuk bentukan-bentukan deposisional yang berupa bentangan dataran alluvial. Satuan bentuk lahan merupakan dataran alluvial dan menempati $20 \%$ dari keseluruhan daerah penelitian. Bentuk lahan alluvial (F1) tersusun atas endapan alluvial material lepas pasir dan lempung serta dicirikan dengan tanah yang subur yang dapat dijadikan lahan pertanian, pemukiman maupun perkebunan. Hal ini didukung karena ketersediaan air di dataran rendah yang melimpah karena endapan alluvial yang ada mampu meyerap air dan menahannya.

\section{Stratigrafi Daerah Penelitian}

Klasifikasi penamaan satuan stratigrafi daerah penelitian menggunakan sistem penamaan stratigrafi resmi yang didasarkan atas ciri litologi dominan yang diamati di lapangan, dan hasil analisa laboratorium (Martodjojo \& Djuheni, 1996). Penamaan satuan batuan pada daerah penelitian berdasarkan ciri - ciri litologi yang terdapat pada lapangan dan lokasi terdapatnya litologi. Secara umum stratigrafi daerah penelitian dibagi menjadi 3 satuan batuan tua ke muda (Gambar 2) adalah sebagai berikut:

1. Satuan batulempung Perjiwa; satuan batuan menempati $\pm 50 \%$ daerah penelitian yang berada di daerah barat lokasi penelitian dan ditandai dengan warna hijau pada peta geologi. Berdasarkan rekonstruksi penampang geologi ketebalan satuan batulempung Perjiwa $\pm 1,5$ meter. Satuan batuan ini beranggotakan batulempung, batupasir, batupasir karbonat, batubara, dan batugamping. Batulempung dengan warna lapuk coklat keabu-abuan, warna segar coklat dengan tekstur ukuran butir lempung, derajat pemilahan terpilah baik, derajat pembundaran membundar dengan kemas tertutup, struktur perlapisan dengan tebal $18 \mathrm{~cm}-4 \mathrm{~m}$. Batupasir dengan warna segar kuning keputihan, tekstur ukuran butir pasir sedang derajat pemilahan terpilah baik, derajat pembundaran membundar dengan tebal $1-2 \mathrm{~m}$. Batubara dengan 
warna lapuk abu abu, warna segar hitam, tekstur amorf cerah coklat, kilap lilin pecahan kubikal, cleath ada parting, tidak ada komposisi karbo, ketebalan $14-45 \mathrm{~cm}$. Batupasir karbonat dengan warna abu-abu kehitaman, padat ukuran butir pasir halus, terpilah baik, membundar, kemas terbuka, fragmen kuarsa, matriks kalsit, semen silika, struktur perlapisan, dan tebal $4 \mathrm{~m}$. Batugamping dengan warna lapuk kuning, warna segar abu abu, struktur fossiliferous, tebal $3 \mathrm{~cm}-2,40$ $\mathrm{m}$.

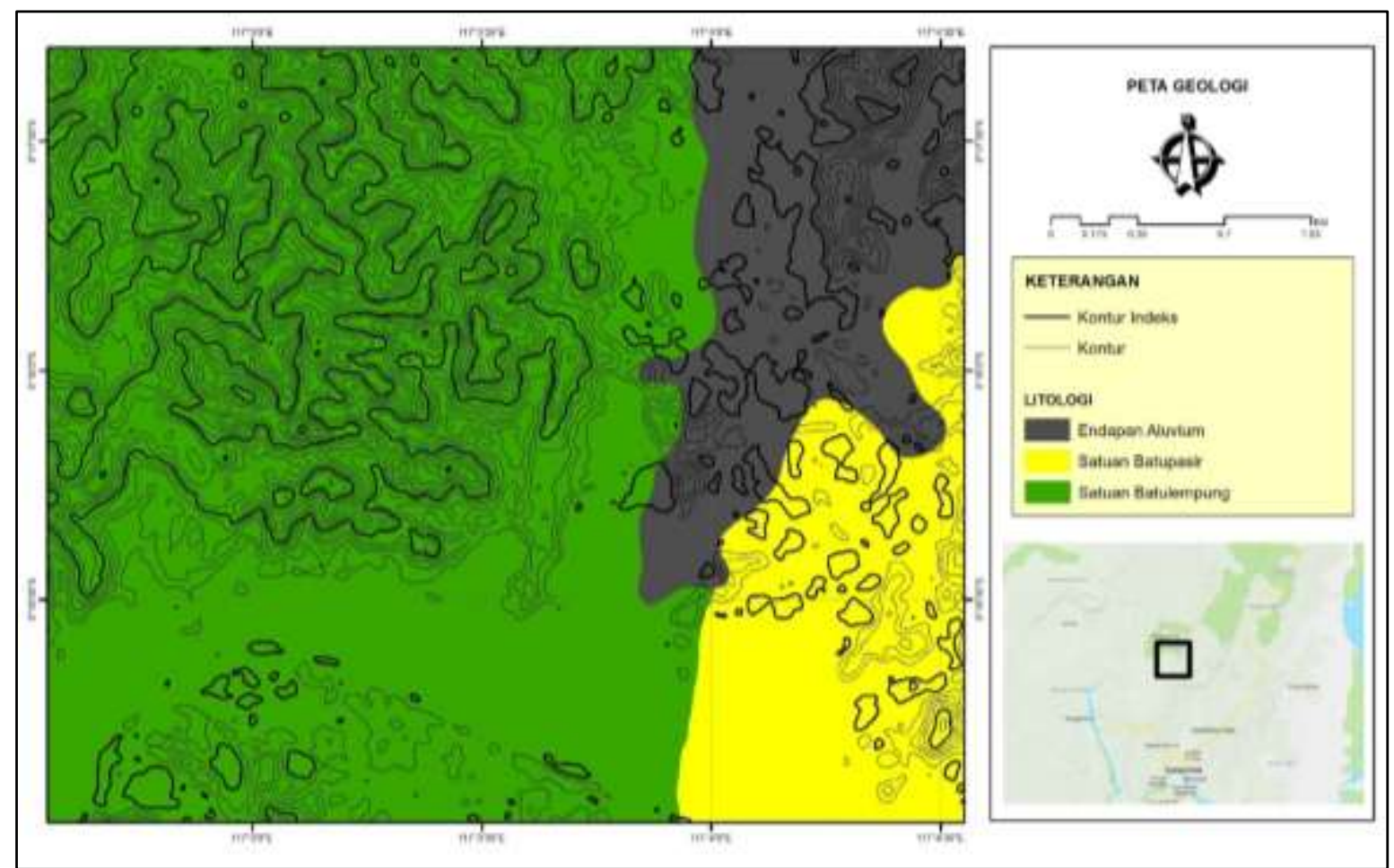

Gambar 2. Peta geologi daerah penelitian.

2. Satuan batupasir Bukit Raya; satuan batuan menempati $\pm 30 \%$ daerah penelitian yang berada di daerah timur lokasi penelitian dan ditandai dengan warna kuning pada peta geologi. Berdasarkan rekonstruksi penampang geologi ketebalan satuan batupasir Bukit Raya \pm 550 meter. Anggota satuan batuan batupasir Bukit Raya terdiri atas batupasir kuarsa dengan sisipan konglomerat, batubara, batupasir sedang dan batulempung. Batupasir kuarsa dengan warna lapuk orange keputihan, warna segar putih, tekstur ukuran butir pasir kasar, derajat pemilahan terpilah buruk, derajat pembundaran agak bundar, kemas terbuka, komposisi fragmen kuarsa, matriks orthoklas, semen silika, struktur silang siur tebal 1 $-3 \mathrm{~m}$. Konglomerat dengan warna lapuk kuning ke-orange-an, tekstur ukuran butir kerikil, derajat pemilahan terpilah buruk, derajat pembundaran agak membundar, kemas terbuka, komposisi fragmen rijang, matriks mineral lempung, semen silika, struktur perlapisan tebal $4-2 \mathrm{~m}$. Batulempung dengan warna lapuk abu abu kehitaman, warna segar abu abu, ukuran butir lempung, terpilah baik, membundar, kemas tertutup, komposisi terdiri dari mineral lempung, semen karbonat, struktur laminasi, dan nama batuan batulempung, tebal $1.5 \mathrm{~m}$. Batupasir sedang memiliki warna lapuk orange keputihan, warna segar putih, ukuran butir pasir sedang, terpilah buruk, agak bundar, kemas terbuka, komposisi fragmen kuarsa, matriks orthoklas, semen karbonat, struktur perlapisan, dan 
nama batuan batupasir.

3. Endapan alluvial ini merupakan endapan darat yang memiliki fragmen material lepas berukuran krakal hingga lempung serta material hasil erosi batuan yang lebih tua dan dikontrol oleh sungai yang memiliki stadia dewasa. Satuan alluvial ini merupakan endapan termuda yang dijumpai pada daerah penelitian. Satuan ini menempati $20 \%$ berupa material lepas - lepas berukuran pasir, kerikil sampai bongkah. Pada peta geologi satuan ini ditandai dengan warna abuabu. Satuan ini memiliki hubungan yang tidak selaras dengan satuan yang ada di bawahnya. Satuan ini berumur HolosenResen karena pengendapan satuan ini masih terus berlangsung sampai saat ini.

\section{Struktur Geologi Daerah Penelitian}

Struktur geologi yang ditemui di lapangan berupa antiklin, sinklin, sesar naik dan sesar mendatar. Berikut merupakan hasil dari analisis data struktur geologi (Gambar 3):

1. Antiklin Perjiwa, antiklin pada daerah penelitian memiliki arah dominan NESW. Antiklin ini pada daerah penelitian dapat dilihat dari kedudukan batuan yang berlawanan. lipatan yang ditemukan pada singkapan tersebut. Klasifikasi lipatan pada di bawah adalah upright horizontal fold (Fluety, 1964). Sedangkan pada stasiun pengamatan 24 dan 25 setelah direkonstruksi lipatannya klasifikasi lipatan yang disimpulkan yaitu upright horizontal fold (Fluety, 1964). Arah gaya dari kedua lipatan dominan NW-SE.

2. Sinklin Perjiwa, sinklin pada daerah penelitian memiliki arah dominan NESW. Sinklin ini pada daerah penelitian dapat dilihat dari kedudukan batuan yang bertemu. Arah gaya yang membentuk sinklin dominan dari arah SE-NW.

3. Antiklin Separi, antiklin pada daerah penelitian memiliki arah dominan NESW. Antiklin ini dicirikan adanya perbedaan kedudukan batuan. Klasifikasi lipatan pada antiklin Separi adalah steeply inclined horizontal fold (Fluety, 1964). Antiklin ini menerus ke arah utara dan arah gaya dominan pada antiklin ini berasal dari NW- SE.

4. Sinklin Bukit Raya, sinklin pada daerah penelitian memiliki arah dominan NESW. Sinklin ini pada daerah penelitian dapat dilihat dari kedudukan batuan yang bertemu. Arah gaya yang membentuk sinklin dominan dari arah SE-NW.

5. Sesar naik Tanjung Batu, sesar naik pada daerah penelitian memiliki arah kelurusan NE-SW yang merupakan sesar naik (Thrust Fault). Indikasi sesar ini dapat dilihat dengan adanya pola sesar ganda dengan bidang sesar yang searah dengan sumbu lipatan, lalu pada sesar ditemukannya mineral karbonat tipis berwarna putih yang mengisi sepanjang zona sesar yang diindiklasikan merupakan hasil dari penggerusan oleh sesar.

6. Sesar naik Bukit Raya, sesar naik pada daerah penelitian memiliki arah kelurusan NE-SW yang merupakan sesar naik (Thrust Fault). Indikasi sesar ini dapat dilihat dengan adanya pola sesar ganda dengan bidang sesar yang searah dengan sumbu lipatan, lalu pada sesar ditemukannya mineral karbonat tipis berwarna putih yang mengisi sepanjang zona sesar yang diindiklasikan merupakan hasil dari penggerusan oleh sesar.

7. Sesar naik menganan KM 5, sesar naik menganan pada daerah penelitian memiliki arah kemenerusan west - east yang merupakan sesar naik menganan. Indikasi sesar naik menganan ini dijumpai adanya cermin sesar pada daerah penelitian dengan adanya mineral lempung tipis ditengah-tengah bidang sesar. Di bidang sesar juga ditemukan adanya bekas seretan yang merupakan hasil dari penggerusan batuan pada saat terbentuk sesar tersebut.

8. Sesar mendatar Tanjung Batu, sesar mendatar pada daerah penelitian 
memiliki arah kelurusan NW-SE yang merupakan sesar mendatar menganan. Indikasi sesar mendatar ini ditemukannya drag fold (lipatan seretan) lalu terlihat adanya perbedaan warna batuan pada batugamping yang secara kontras dan terlihat bahwa antiklin pada lokasi penelitian terpotong oleh sesar mendatar menganan. Data data tersebut menunjukkan sesar mendatar menganan Tanjung Batu.

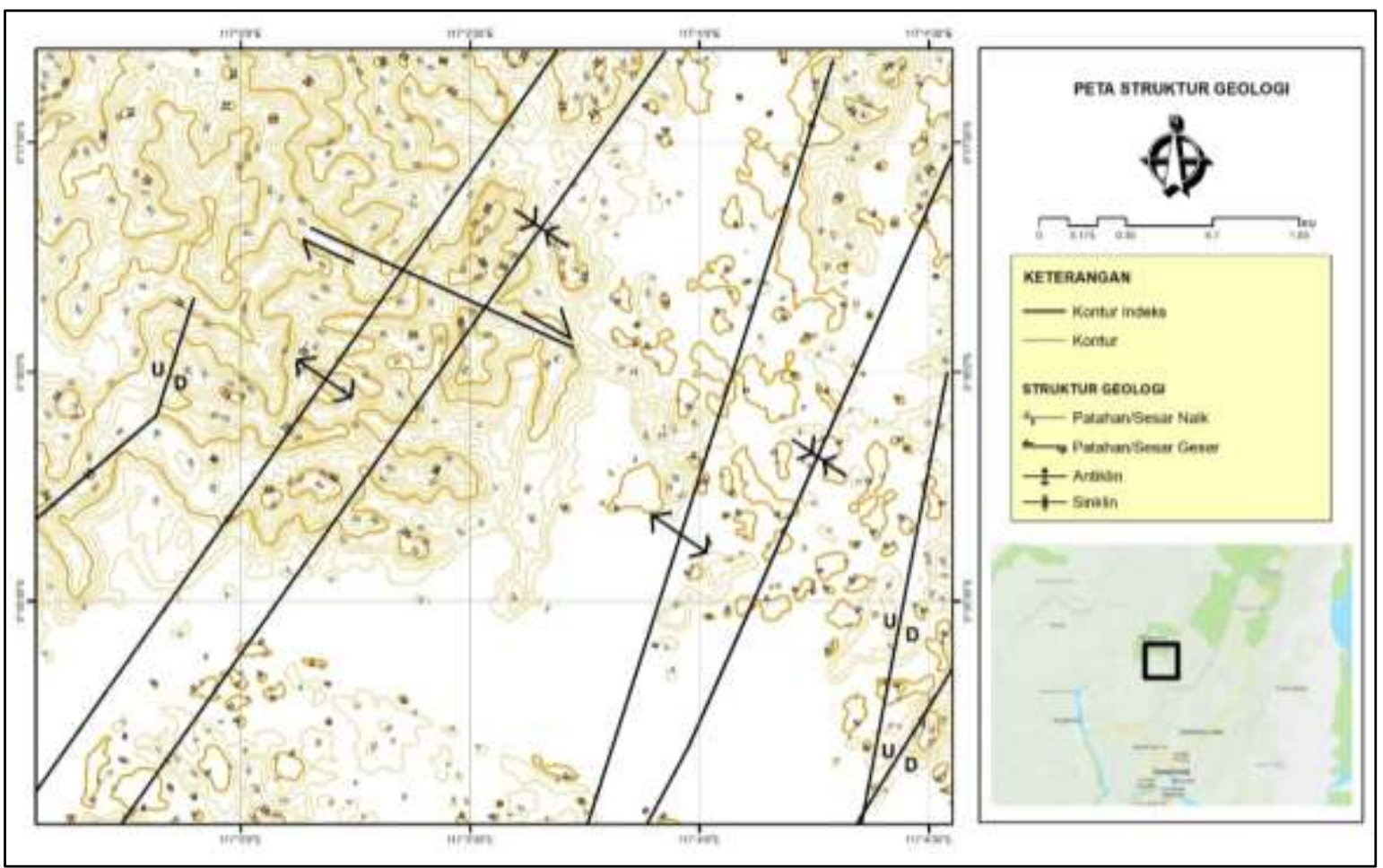

Gambar 3. Peta geologi struktur daerah penelitian.

\section{Mekanisme Struktur geologi}

1. Pembentukan lipatan (Gambar 4); adanya gaya tektonik yang menghasilkan gaya kompresi dengan arah tegasan utama baratlaut - tenggara menyebabkan terbentuknya perlipatan

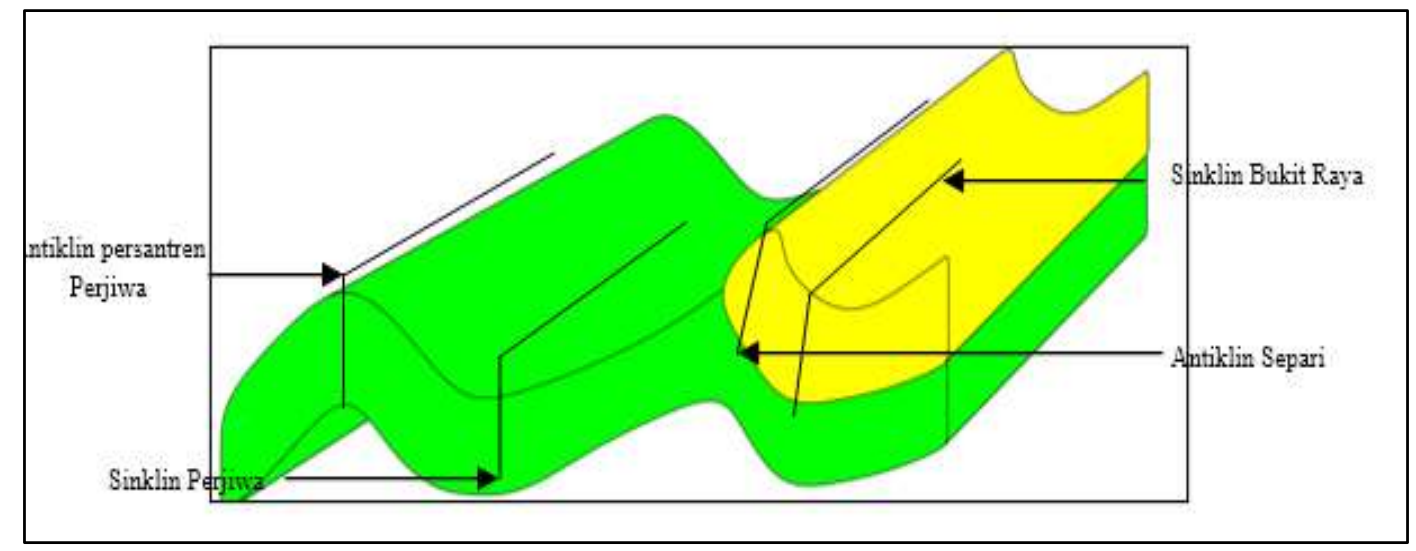

Gambar 4. Mekanisme pembentukan lipatan.

2. Pembentukan sesar naik (Gambar 5), gaya yang terus bekerja menyebabkan pada daerah penelitian. Terbentuknya lipatan ini searah dengan arah tegasan utama dengan gaya kompresi. Lipatan ini terbentuk pada saat kala Pliosen. 
mengakibatkan batuan tersebut mengalami fasa deformasi plastis yaitu dengan terbentuknya kekar, gaya kompresi terus berlanjut hingga menghasilkan gaya tarik yang relatif tegak lurus dengan tegasan maksimum. Apabila tekanan pada batuan terus ditingkatkan maka rekahan batuan akan membentuk patahan. Berdasarkan data lapangan yang diperoleh arah gaya sesar yang diperoleh berasar dari baratdaya tenggara, sehingga membentuk sesar naik pada daerah penelitan. Sesar naik diperkirakan terbentuk pada umur Plistosen. Sesar naik yang terbentuk pada daerah penelitian adalah sesar naik Bukit Raya lalu terbentuk sesar naik KM 5 dan sesar naik yang terakhir terbentuk adalah sesar naik Perjiwa.

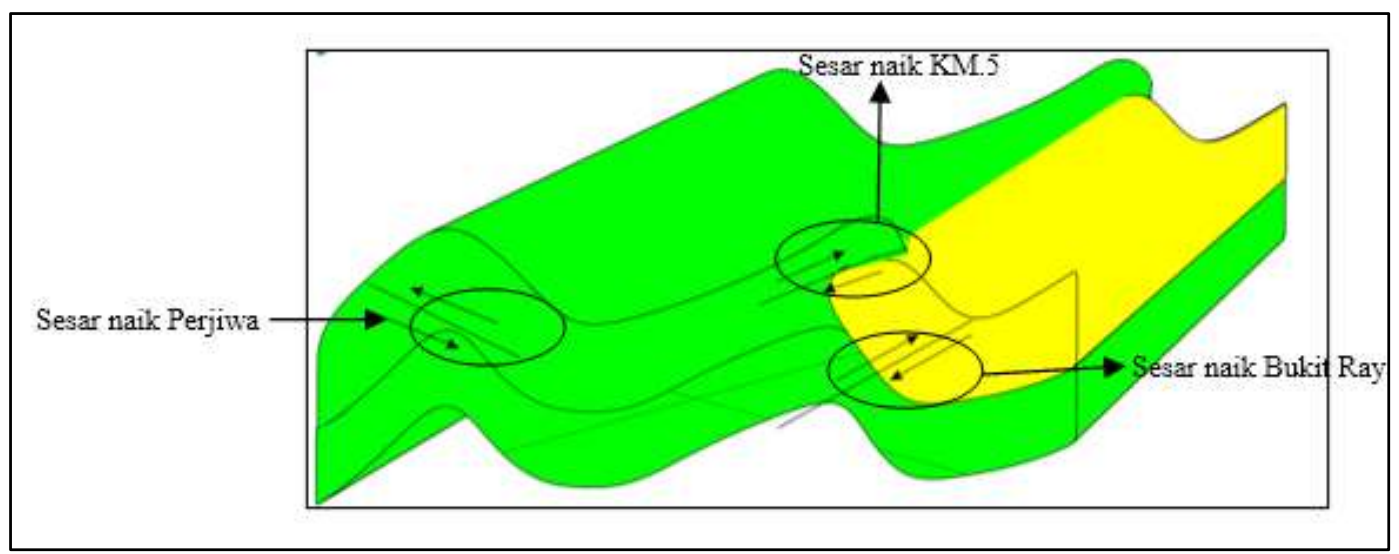

Gambar 5. Mekanisme pembentukan sesar naik.

3. Pembentukan sesar mendatar (Gambar 6), selanjutnya gaya kompresi terus bekerja dan semakin meningkat yang mengakibatkan batuan tersebut akan patah dan bergeser dan membentuk sesar mendatar menganan. Sumbu utama tegasan relatif berarah tenggara baratlaut dan bidang sesarnya relatif tenggara - baratlaut. Sesar mendatar ini terbentuk pada saat Pliosen. Setelah terbentuknya sesar naik, gaya kompresi yang bekerja tersebut berhenti.

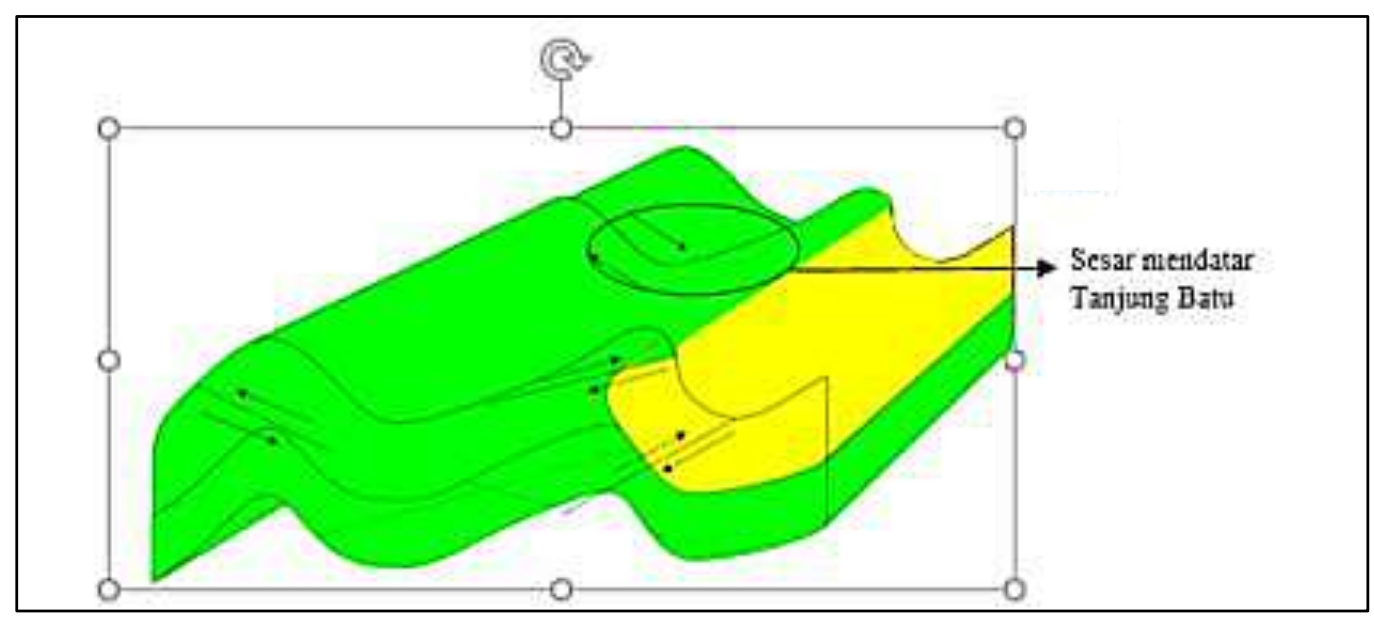

Gambar 6. Mekanisme pembentukan sesar mendatar.

\section{Kesimpulan}

Hasil penelitian terdapat 3 satuan batuan antara lain satuan batulempung Perjiwa, satuan batupasir Bukit Raya, satuan endapan alluvial. Satuan bentuk asal dibagi menjadi 2 yaitu bentuk asal struktural dan fluvial. Pada lokasi penelitian terdapat antiklin Perjiwa, sinklin Perjiwa, antiklin Separi, sinklin Separi, sesar naik Perjiwa, 
sesar naik Bukit Raya, sesar naik KM 5 dan sesar mendatar Tanjung Batu. Mekanisme struktur geologi yang terbentuk pertama yaitu terbentuknya lipatan lalu terbentuk sesar naik dan terakhir terbentuk sesar mendatar. Pengaruh struktur geologi terletak pada kedudukan batuan yaitu semakin menuju ke arah antiklin kedudukan batuan semakin terjal dan semakin menuju ke arah sinklin lapisan batuan menjadi datar.

\section{Daftar Pustaka}

Allen, G.P dan Chambers, J.L.C. 1998. Sedimentation in the Modern Delta and Miocene Mahakam Delta. Jakarta, Indonesia: Indonesian Petroleum Association.

Fluety, M.J. 1964. The Description of Folds. Proceedings of the Geologists Association. 75(4), pp.461-492.

https://doi.org/10.1016/S00167878(64)80023-7

Martodjojo, S. dan Djuheni. 1996. Sandi Stratigrafi Indonesia. Bandung: Komisi Sandi Stratigrafi Indonesia. IAGI. https://www.iagi.or.id/wpcontent/uploads/2012/04/SandiStratigrafi-Indonesia-1996.pdf

McClay, K., Dooley, T., Ferguson, A. dan Poblet, J. 2000. Tectonic Evolution of the Sanga-Sanga Block, Mahakam Delta, Kalimantan, Indonesia. AAPG Buletin. 84(6), pp.765-786.

http://dx.doi.org/10.1306/A96733E C-1738-11D7-8645000102C1865D

Nugraha, A., Pambudi, F., Septia, V.S., Sugiarto, S. dan Hussein, S. 2016. Karakteristik Deformasi Struktur pada Sistem Kompleks Sesar Mendatar Trembono di Dusun Sumberan, Kecamatan Ngawen Kabupaten Gunung Kidul. In Seminar Nasional kebumian Ke-9, 6-7 Oktober 2016, Yogyakarta, pp. 21-33
Supriatna S., Sukardi R., dan Rustandi E. 1995. Peta Geologi Lembar Samarinda, Kalimantan. Bandung: Pusat Penelititan dan Pengembangan Geologi. 